\title{
Morphological characteristics and cell viability of coffee plants calli
}

\author{
Características morfológicas e viabilidade celular de calos de cafeeiro
}

\author{
Marlúcia Souza PáduaI Luciano Vilela Paiva ${ }^{I}$ Luciano Coutinho da SilvaII \\ Kalynka Gabriella do Livramento ${ }^{\mathrm{I}}$ Eduardo Alves $^{\mathrm{III}}$ Ana Hortência Fonseca Castro ${ }^{\mathrm{IV}}$
}

\section{ABSTRACT}

The aim of this research was to characterize and compare two types of calli from leaf explants of Coffea arabica (cultivar Catiguá). Cells of different types of callus were successfully characterized regarding viability and internal and external morphological characteristics. It was obtained two morphologically distinct types of callus: (i) yellow friable and (ii) transparent watery. The yellow friable calli showed higher cell viability and embryogenic characteristics. Scanning and transmission electron microscopy showed embryogenic characteristics in cells of the yellow friable calli evidenced by the presence of small and isodiametric cells, while transparent watery calli showed elongated cells and large cytoplasm vacuolization.

Key words: Coffea arabica, electron microscopy, tetrazolium test.

\section{RESUMO}

O objetivo deste trabalho foi caracterizar e comparar dois tipos de calos de explantes foliares de Coffea arabica (cultivar Catiguá). Células de diferentes tipos de calos foram caracterizadas quanto a viabilidade e características morfológicas externas e internas. Foram obtidos dois tipos de calos morfologicamente distintos: (a) amarelo friável e (b) transparente aquoso. Os calos amarelos friáveis apresentaram maior viabilidade celular e características embriogênicas. Microscopia eletrônica de varredura e transmissão mostraram características embriogênicas em calos amarelos friáveis evidenciadas pela presença de células pequenas e isodiamétricas. Os calos transparentes aquosos apresentaram células alongadas e vacuolizadas.

Palavras-chave: Coffea arabica, microscopia eletrônica, teste do tetrazólio.

\section{INTRODUCTION}

Coffee is one of the world's major commodities, and Brazil ranks first in production, consumption, and export (AGRIANUAL, 2013). However, Coffea arabica L. has propagation problems by conventional cutting methods concerning long life cycle, phenological characteristics of the species, and environmental influences (ROSA et al., 2007).

The somatic embryogenesis can be employed to promote rapid in vitro multiplication of coffee plants recommended for planting, as hybrids from breeding programs. According RIBAS et al. (2011), currently, embryogenic callus derived from leaf tissues is the most widely used target tissue for the genetic transformation of $\mathbf{C}$. arabica and different callus stages can affect plant transformation. However, the induction of embryogenic tissues in C. arabica takes longer and is more difficult than in the others cultivated species. The limited vailability of embryogenic tissues, together with the low transformation efficiency of this type of tissue is one of the main limitations to genetic transformation in coffee.

Distinction between embryogenic and nonembryogenic callus is important to improve protocols for induction and regeneration of somatic embryos in vitro so, procedures to estimate cell viability have become necessary. SILVA \& MENENDÉZ-YUFFÁ

\footnotetext{
'Programa de Pós-graduação em Biotecnologia Vegetal, Departamento de Química, Universidade Federal de Lavras (UFLA), Lavras, MG, Brasil.

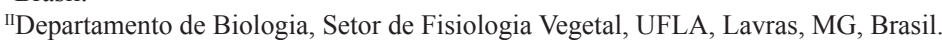

IIIDepartamento de Fitopatologia, Laboratório de Microscopia Eletrônica e Análise Ultraestrutural, UFLA, Lavras, MG, Brasil.

IVPrograma de Pós-graduação em Ciências Farmacêuticas, Universidade Federal de São João del-Rei (UFSJ), Campus Centro-Oeste, 35501-296, Divinópolis, MG, Brasil. E-mail: acastro@ufsj.edu.br. Autor para correspondência. Received 04.24.13 Approved 09.30.13 Returned by the author 01.17.14 CR-2013-0571.R1
} 
(2006) reported that the methods used to evaluate the presence of viable and non-viable cells can be classified in two groups: those that stain only the dead cells, and those in which only the living cells are coloured, because the colour is a product of cell metabolic activity. Acetocarmine enables inferring chromosomal integrity and characterization of viable cells (STEINER et al., 2005; MUNHOZ et al., 2008), while Evans Blue enters damaged cell walls in apoptosis process, allowing for identification of nonviable cells (BHARGAVA et al., 2007). Viability can also be quantified with activity assays, using for example the 2, 3, 5-triphenyltetrazolium chloride (TTC). In the mitochondrial electron transport chain, TTC is reduced to triphenylformazan (TPF) and acts as final electron acceptor in place of oxygen. This reaction corresponds to cellular respiration and indicates cell metabolic activity and viability (DIAS \& ALVES, 2008).

Morphological and ultrastructural features of cells can be visualized by electron microscopy, which allows inferring characteristics of embryogenic cells, such as isodiametric shape, small size, large nucleus, visibly evident nucleus, and organelles related to increased cell metabolism. In addition, electron microscopy can also identify features of nonviable cells, such as elongated and vacuolated cells (NOGUEIRA et al., 2007).

Taken together these analysis may identify calli with embryogenesis characteristics in early stages of calli culture. In this study it was characterized and compared two types of calli from leaf explants of coffee plants for cellular shape, viability and ultrastructural features, enabling the improvement of protocols for in vitro plant regeneration by indirect embryogenesis.

\section{MATERIAL AND METHODS}

The experiments were performed in the Central Laboratory of Molecular Biology and Laboratory of Electron Microscopy and Ultrastructural Analysis of the Federal University of Lavras (UFLA), Lavras, MG.

\section{Callus induction}

For callus induction it was used plant leaf explants of Coffea arabica cv. 'Catiguá MG2' maintained in a greenhouse. Leaves were washed in running water for 10 minutes and in the laminar air flow, they were decontaminated in $\mathrm{NaOCl}\left(40 \mathrm{~g} \mathrm{~L}^{-1}\right.$ dissolved in water) for 20 minutes, and washed in autoclaved distilled water three times for 10 minutes.
The explants were inoculated in a BERTHOULY \& MICHAUX-FERRIÈRRE medium (1996) modified for calli induction, supplemented with $2.26 \mu \mathrm{M}$ 2,4-D; $5 \mu \mathrm{M}$ IBA; $10 \mu \mathrm{M} 2 \mathrm{iP} ; 200 \mathrm{mg} \mathrm{L}^{-1}$ inositol; $400 \mathrm{mg} \mathrm{L}^{-1}$ malt extract; $100 \mathrm{mg} \mathrm{L}^{-1}$ casein; $10 \mathrm{mg} \mathrm{L}^{-1}$ thiamine; $1 \mathrm{mg} \mathrm{L}^{-1}$ nicotinic acid; $1 \mathrm{mg} \mathrm{L}^{-1}$ pyridoxine; $1 \mathrm{mg} \mathrm{L}^{-1}$ glycine; $\mathrm{L}^{-1} 30 \mathrm{~g}$ sucrose; $6 \mathrm{~g} \mathrm{~L}^{-1}$ agar; and $\mathrm{pH}$ adjusted to 5.7 or 5.8. The explants were maintained in a growth chamber at $25^{\circ} \mathrm{C}$ in the dark. After three weeks, they were transferred to a BERTHOULY \& MICHAUX-FERRIÈRRE medium (1996) modified for embryogenic calli induction, supplemented with $17 \mu \mathrm{M}$ BAP and $4.52 \mu \mathrm{M} 2,4-\mathrm{D} ; 60 \mathrm{mg} \mathrm{L}^{-1}$ adenine; $200 \mathrm{mg} \mathrm{L}^{-1}$ inositol; 200mg L $\mathrm{m}^{-1}$ malt extract; $100 \mathrm{mg} \mathrm{L}^{-1}$ casein; $20 \mathrm{mg} \mathrm{L}^{-1}$ thiamine; $20 \mathrm{mg} \mathrm{L}^{-1}$ glycine; $40 \mathrm{mg} \mathrm{L}^{-1}$ L-cysteine; $30 \mathrm{~g} \mathrm{~L}^{-1}$ sucrose; $6 \mathrm{~g} \mathrm{~L}^{-1}$ agar; $\mathrm{pH}$ adjusted to 5.7 or 5.8. After five months, two types of callus were characterized: (i) a yellow friable and (ii) a transparent watery, and used in subsequent experiments.

Cell viability

Analysis was performed using tetrazolium test (BENSON, 1994) with five replications of 50mg callus collected from five dishes, and the level of cell viability was calculated according to the amount of triphenylformazan produced by living cells. To assess pro-embryogenic characteristics by double staining with acetocarmine and Evans Blue, 25mg callus were collected for each replication, amounting to five replications. Samples were prepared according to DURZAN (1988). Callus cells were visualized in 10x and 20x objective lens in photonic microscope (Leica DM LS ${ }^{\circledR}$ microscope with Nikon ${ }^{\circledR}$ camera attached). The areas stained with acetocarmine (AC) and Evans Blue (EB) were measured with ImageTool software. $\mathrm{AC}$ and $\mathrm{EB}$ areas were added to provide total area and percentage of each area was obtained for statistical analysis. Data was analyzed in a completely randomized design (CRD) with 25 replications for each type of callus. Sisvar 5.0 software (FERREIRA, 2008) provided statistical analysis, and the means were analyzed by Scott-Knott test at $5 \%$ nominal level of significance.

\section{Electron microscopy}

For scanning electron microscope analysis, samples of both types of callus were immersed in fixative (modified Karnovsky, 2.5\% glutaraldehyde, $2.0 \%$ paraformaldehyde, $0.05 \mathrm{M}$ cacodylate buffer, $\mathrm{pH}$ 7.2) for $24 \mathrm{~h}$, and prepared according to the BOSSOLA \& RUSSELL (1998) protocol. Samples were observed through the LEO Evo 40 scanning 
electron microscope, and cell dimensions (width and length) were assessed using the Smart User Interface (Zeiss) program. The experiment used a completely randomized design (CRD) with 50 replications per treatment. For statistical analysis it was used Sisvar 5.0 software (FERREIRA, 2008), and the means were analyzed by Scott-Knott test at 5\% significance level. For analysis in Zeiss EM 109 transmission electron microscope, samples were prepared according to the BOSSOLA \& RUSSELL (1998) protocol.

\section{RESULTS AND DISCUSSION}

It was observed two morphologically distinct types of callus: (i) yellow friable and (ii) transparent watery. Tetrazolium viability test showed the mean absorbance values 0.4340 and 0.0643 for the yellow friable and the transparent watery callus, respectively. According to DIAS \& ALVES (2008), TTC chloride (2,3,5 - triphenyl tetrazolium chloride) is colorless in the oxidized form and red when reduced to TFF (triphenylformazan). The viability of plant tissue is proportional to the amount of TFF produced by living cells (SILVA \& MENENDĖZ-YUFFÁ, 2006), and is also related to red color intensity.

Results of double staining with acetocarmine (AC) and Evan Blues (EB) showed that $\mathrm{AC}$ reacted in $84.79 \%$ cells in the yellow friable callus, and in $28.55 \%$ cells in the transparent watery. Conversely, the yellow and friable reacted less to EB
(15.21\% of cells), whereas the transparent watery reacted in $71.45 \%$. Cells in the yellow friable callus were small, round (isodiametric), arranged in clusters, and $\mathrm{AC}$ reactive; cells in the watery transparent callus were elongated and EB reactive (Figure 1). The results showed that the yellow friable callus has higher cell viability, wich may contribute to a higher potential for embryogenesis, as strongly AC reactive cells have embryonic characteristics, according to CANGAHUALA-INOCENTE et al. (2007).

Our data corroborate the findings of STEINER et al. (2005), who emphasized the AC affinity for small isodiametric cells and EB affinity for elongated cells in callus of Araucaria angustifolia. EB penetrates membrane ruptures, turning cell interior blue early indicating cell deth (BHARGAVA et al., 2007). GATICA-ARIAS et al. (2008) evaluated the embryogenic viability of cells suspensions of coffee plants using EB stain. The results showed that nonviable cells turned intensely blue, whereas viable cells did not react and showed isodiametric shape, dense cytoplasm, and nucleus with prominent nucleoli. According to MUNHOZ et al. (2008), positive reaction to AC demonstrates chromosomal integrity.

Scanning electron microscopy showed that round cells arranged in clusters, with diameters $24 \times 21 \mu \mathrm{m}$, characterizing a spherical shape predominated in the yellow friable callus and elongated cells, with diameters $268 \times 36 \mu \mathrm{m}$ and showed

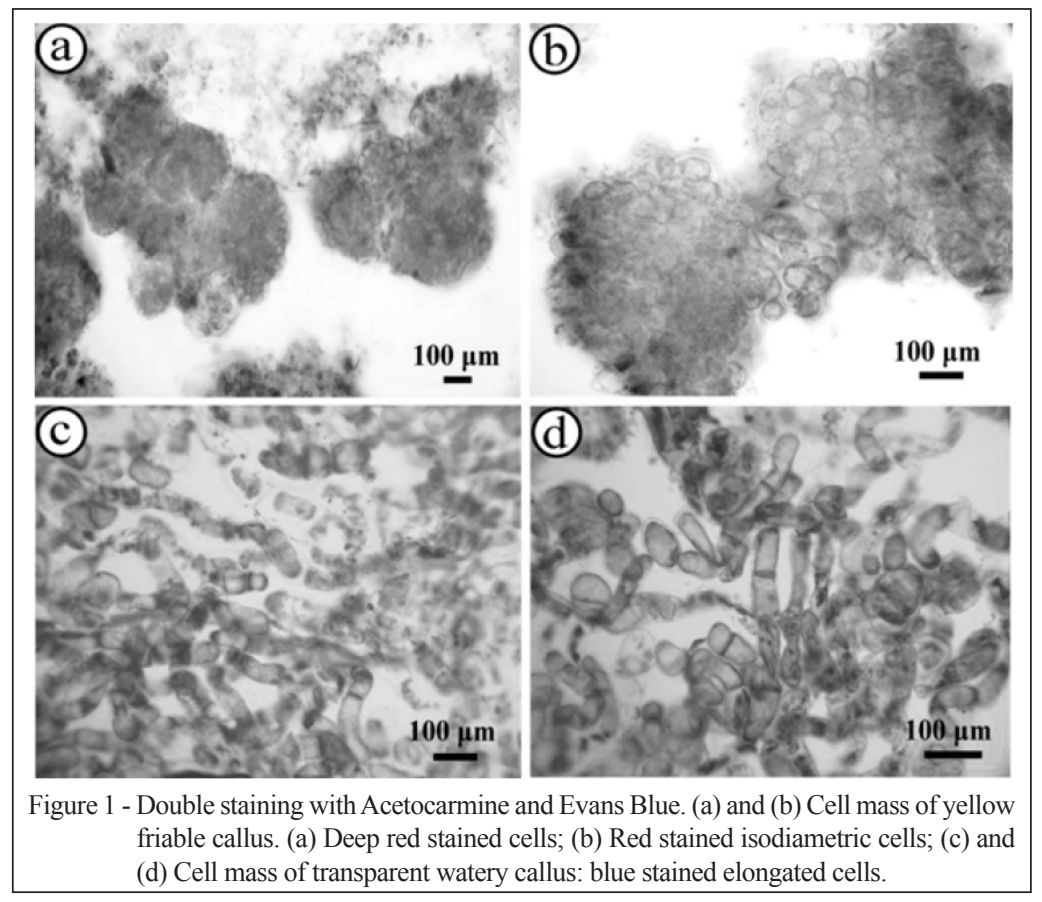

Ciência Rural, v.44, n.4, abr, 2014. 
dispersed disposition in the transparent watery callus (Figure 2). These results are in agreement with those described by SONDAHL et al. (1979) that obtained from leaf explants two distinct cell populations of the callus tissue: one consisting of elongated cells and the other of small spherical embryogenic cells. The small spherical cells became separated from one another and subsequently, differentiation of the embryogenic cells into globular forms of coffee embryos occurred. NAKAMURA et al. (1992) described by scanning electron microscopy that callus derived from mature leaves of $\boldsymbol{C}$. arabica has shown the presence of small spherical cells, characteristic of embryogenic tissues. The presence of small meristematic cells with diameter range of 15 to $20 \mu \mathrm{m}$ were observed in globular callus of coffee plants and showed small isodiametric cells (QUIROZ-FIGUEROA et al., 2002). BOBÁK et al. (2004) reported that in Drosera spathulata Labill, callus showing grouping of small, irregular and isodiametric cells originated embryos which passed through heart, torpedo and cotyledonary stages, and finally regenerated seedlings.

Transmission electron microscopy showed that cells of the yellow friable callus had dense cytoplasm, nuclei with prominent nucleoli, a large number of amyloplasts, and absence of vacuoles.
Cells of the transparent watery callus, however, showed an autophagic vacuole occupying the whole cytoplasmic space, vesicles, increased intercellular space, and absence of other cytoplasmic organelles (Figure 3). These results confirm the findings of NOGUEIRA et al. (2007), who reported disorganized nuclei and few cytoplasmic organelles in cells of Byrsonima intermedia callus in the first subculture.

According to FUKUDA (2000), autophagy may be involved in degradation of cell contents, and the vacuole plays a central role in the process of programmed cell death. Our results are also similar to those achieved by ASLAM et al. (2011), who analyzed Phoenix dactylifera L. and for STEINMACHER et al. (2011) in callus cells of Bactris gasipaes. The authors found embryogenic cells with well-developed nucleus, prominent nucleoli, and starch granules. NAKAMURA et al. (1994) studied callus cells of somatic embryos of Coffea cvs. 'Mundo Novo' and 'Catuaí Amarelo' and reported this biochemical pattern as the primary source of energy needed for intense cell division and embryo development. The consumption of starch grains provide energy for developing somatic embryos, which suggests active regulation of the amount of starch in callus.

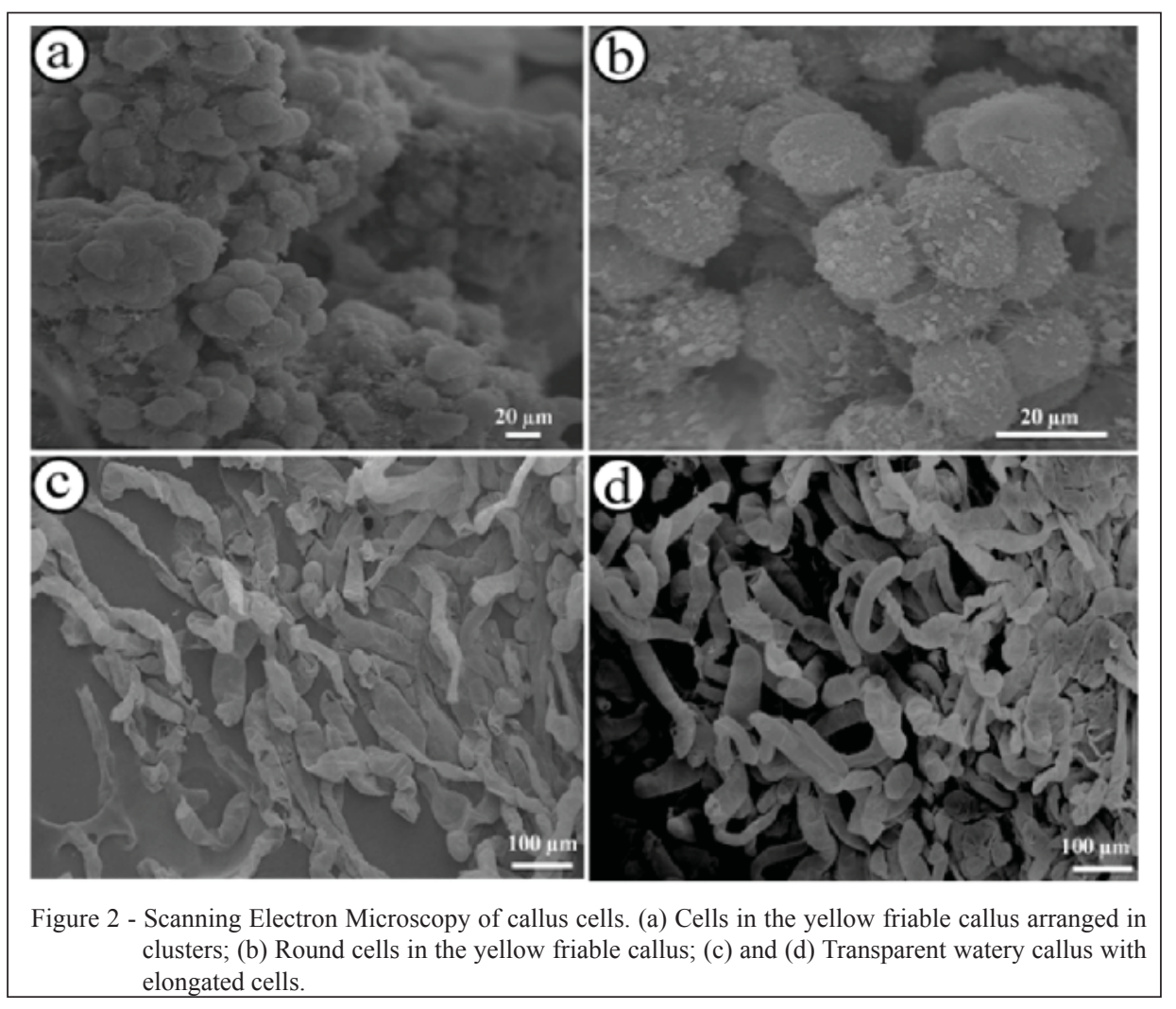

Ciência Rural, v.44, n.4, abr, 2014. 


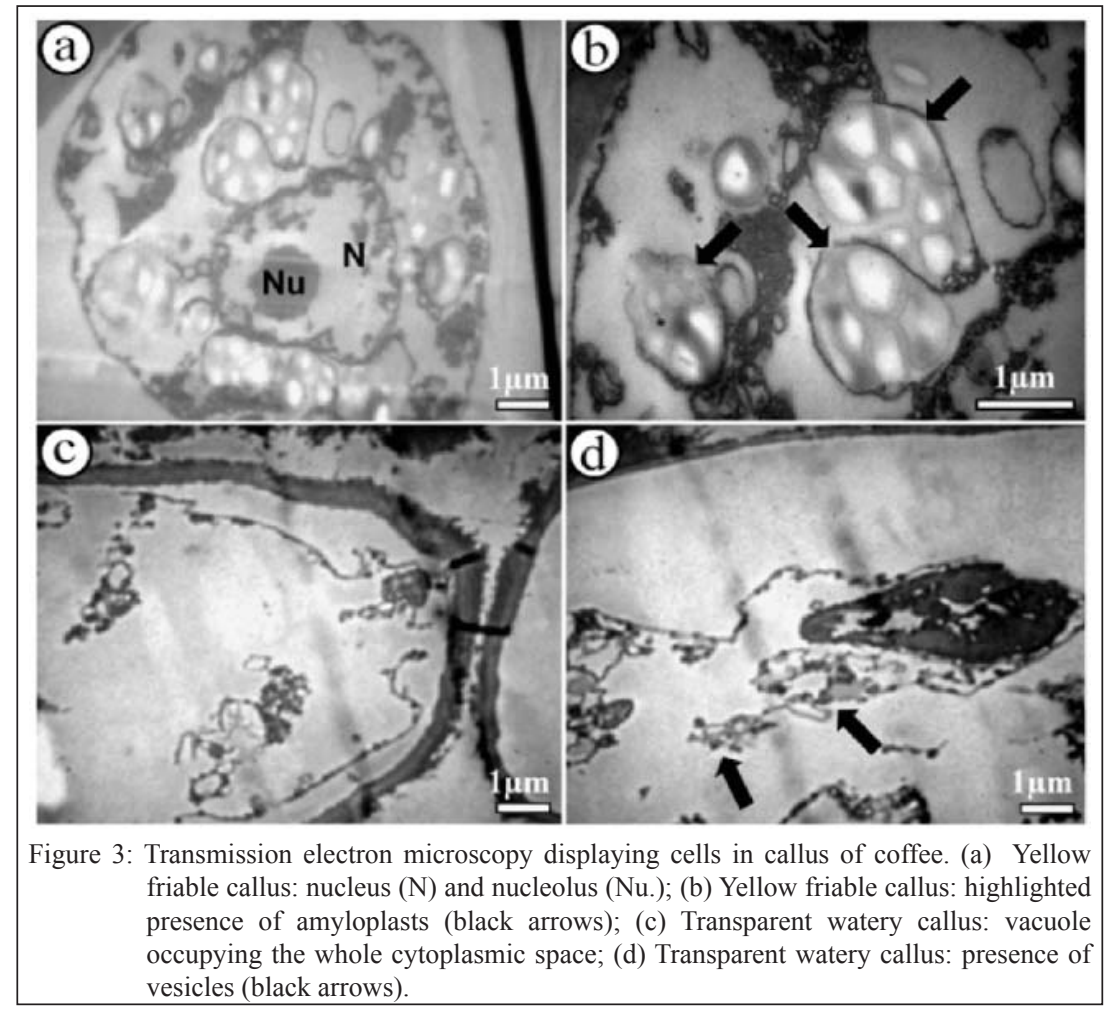

\section{CONCLUSION}

In Coffea arabica cv. 'Catiguá' yellow friable callus showed embriogenic characteristics and higher cell viability.

\section{AKNOWLEDGMENTS}

To the Laboratory of Electron Microscopy and Ultrastructural Analysis, the Conselho Nacional de Desenvolvimento Científico e Tecnológico (CNPq), the FAPEMIG, and the CAPES.

\section{REFERENCES}

AGRIANUAL 2013. Anuário da agricultura brasileira. 18.ed. São Paulo: FNP Consultoria e Comércio, 2013. 480 p.

ASLAM, J. et al. Somatic embryogenesis, scanning electron microscopy, histology and biochemical analysis at different developing stages of embryogenesis in six date palm (Phoenix dactylifera L.) cultivars. Saudi Journal of Biological Sciences, v. 18 , n. 4 , p. 369-380, 2011. Available from: <http://www. sciencedirect.com/science/journal/1319562X/18>. Acessed at 23 jan. 2012. doi:10.1016/j.sjbs.2011.06.002.

BENSON, E. E. Cryopreservation. In: DIXON, R. A.; GONZALES, R.A. Plant cell culture: a practical approach. 2.ed. Oxford: IRL, 1994. Cap.7, p. 147-167.

BERTHOULY, M.; MICHAUXFERRIERE, N. High frequency somatic embryogenesis in Coffea canephora. Plant Cell Tissue and Organ Culture, v. 44, n.2, p. 169176, 1996. Available
from:<http://link.springer.com/article/10.1007\%2FBF00048196> Acessed at 08 fev. 2013

BHARGAVA, A. et al. Expression of a polyphemusin variant in transgenic tobacco confers resistance against plant pathogenic bacteria, fungi and a virus. Plant Cell Tissue and Organ Culture, v. 88 , n. 3, p. 301-312, 2007. Available from: <http://www.cmdr. ubc.ca/bobh/rjpdocs/351 2007 PlantCellTissOrgCult 88 p301. pdf $>$. Acessed at 22 nov. 2011. doi: 10.1007/s11240-007-9204-9.

BOBÁK, M. et al. The histological analysis of indirect somatic embryogenesis on Drosera spathulata Labill. Acta Physiologiae Plantarum, v. 26, n.3, p.353-361, 2004. Available from: <http:// link.springer.com/article/10.1007\%2Fs 11738-004-0025-8>. Acessed at 23 out. 2011.

BOSSOLA, J. J.; RUSSELL, L. D. Electron Microscopy. 2.ed. Boston: Jones and Bartlett Publishers, 1998, 680p.

CANGAHUALA-INOCENTE, G. C. et al. Competência embriogenética em tecidos florais de Acca sellowiana (Myrtaceae). Revista Brasileira de Biociências, v. 5, supl. 2, p. 87-89, 2007. Available from: <http://www.ufrgs.br/seerbio/ojs/index.php/rbb/ article/view/120/118>. Acessed at 29 nov. 2011.

DIAS, M. C. L. de L.; ALVES, S. J. Avaliação da viabilidade de sementes de Brachiaria brizantha (Hochst ex. A Rich) Stapf. pelo teste de tetrazólio. Revista Brasileira de Sementes, v. 30, n. 3, p. 145-151, 2008. Available from: <http://www.scielo.br/scielo. php? script $=$ sci arttext\&pid $=$ S0101-31222008000300019\&ln $\mathrm{g}=\mathrm{pt \& nrm}=\mathrm{iso}>$. Acessed at 23 jan. 2012. doi: http://dx.doi. org/10.1590/S0101-31222008000300019.

DURZAN, D.J. Process control in somatic polyembryogenesis In: Hallgren, J.E. (Ed). Frans Symposium Departament of Forest 
Genetics and Plant Physiology, Swedish. Proceedings... Swedish: University of Agricultural Sciences, v. 8, p. 147-186, 1988.

FERREIRA, D. F. SISVAR: Um programa para análise e ensino de estatística. Revista Symposium, v. 6, n. 2, p. 36-41, 2008.

FUKUDA, H. Programmed cell death of tracheary elements as a paradigm in plants. Plant Molecular Biology, v. 44, n. 3, p.245253, 2000. Available from: <http://www.bb.iastate.edu/ thorn/ BBMB607/2004-PCD/PDF_Files/Tracheary_PCD_is_paradigm. pdf $>$. Acessed at 20 out. 2011. doi: 10.1023/A:1026532223173.

GATICA-ARIAS, A. M. et al. Plant regeneration via indirect somatic embryogenesis and optimisation of genetic transformation in Coffea arabica L. cvs. 'Caturra' and 'Catuaí'. Electronic Journal of Biotechnology, v. 11, n. 1, p. 101-112, 2008. Available from: <http://www.ejbiotechnology.info/index.php/ ejbiotechnology/article/viewFile/v11n1-9/72>. Acessed at jan. 23, 2012. doi: 10.2225/vol11-issue1-fulltext-9.

MUNHOZ, M. et al. Viabilidade polínica de Carica papaya L.: uma comparação metodológica. Revista Brasileira de Botânica, São Paulo, v. 31, n. 2, p. 209-214, 2008. Available from: <http:// www.scielo.br/scielo.php? script $=$ sci_arttext\&pid $=\mathrm{S} 0100$ $84042008000200003 \& \operatorname{lng}=$ pt\&nrm $=$ iso $>$. Acessed at 03 out. 2010. http://dx.doi.org/10.1590/S0100-84042008000200003.

NAKAMURA, T. et al. Cyto-histological studies on somatic embryos of Coffee: ultrastructural aspects. Japanese Journal of Crop Science, v. 63, n. 1, p. 144-157, 1994. Available from: $<$ https://www.jstage.jst.go.jp/result?cdjournal=jcs\&item $1=4 \& w o$ rd1 $=$ Cyto-histological + studies + on + somatic + embryos + of + Coffee $\% 3 \mathrm{~A}+$ ultrastructural+aspects $>$. Acessed at 23 jan. 2012.

NAKAMURA T. et al. Studies on somatic embryogenesis of coffee by scanning electron microscope. Japanese Journal of Crop Science, v. 61, n.3, p. 476-486, 1992. Available from: <https:// www.jstage.jst.go.jp/result?cdjournal=jcs\&item $1=4 \&$ word $1=$ Stud ies + on + somatic + embryogenesis + of + coffee + by + scanning + electro $\mathrm{n}+$ microscope $>$. Accessed at 08 fev. 2013.

NOGUEIRA, R. C. et al. Análise ultra-estrutural de calos embriogênicos de murici-pequeno (Byrsonima intermedia A. Juss.). Revista Brasileira de Biociências, v.5, n. 2, p.48-50, 2007. Available from: <http://www.ufrgs.br/seerbio/ojs/index.php/rbb/ article/view/90/86>. Acessed at 23 jan. 2012.
QUIROZ-FIGUEROA, F. R. et al. Histological studies on the developmental stages and differentiation of two different somatic embryogenesis systems of Coffea arabica. Plant Cell Reports, v. 20 , n. 3, p. 1141-1149, 2002. Available from: <http://www. springerlink.com/content/jxd38tbcd15bblwv/>. Acessed at 11 nov. 2011. doi: http://dx.doi.org/10.1007/s00299-002-0464-x.

RIBAS, A. F. et al. Agrobacterium-mediated genetic transformation of Coffea arabica (L.) is greatly enhanced by using established embryogenic callus cultures. BMC Plant Biology, v. 11, n. 92, p. 1-15, 2011. Available from: <http://www.biomedcentral.com/ content/pdf/1471-2229-11-92.pdf $>$. Acessed at 04 jan. 2013. doi: http://dx.doi.org/10.1186/1471-2229-11-92.

ROSA, S. D. V. F. et. al. Pré-embebição: Efeitos na germinação, crescimento de plântulas e teor de cafeína em sementes de cafeeiro. Coffee Science, v.2, n. 1, p. 69-78, 2007. Available from: <http:// www.coffeescience.ufla.br/index.php/Coffeescience/article/ view/41/127>. Acessed at 11 nov. 2011.

SILVA, R. F. da; MENÉNDEZ-YUFFÁ, A. Viability in protoplasts and cell suspensions of Coffea arabica cv. 'Catimor'. Electronic Journal of Biotechnology, v.9, n.5, p. 250-257, 2006. Available from:<http:/www.ejbiotechnology.info/content/vol9/issue5/ full/4/4.pdf $>$. Acessed at 12 jan. 2013. doi: 10.2225/vol9-issue5fulltext-4.

SONDAHL, M. R.et al. SEM characterization of embryogenic tissue and globular embryos during high frequency somatic embryogenesis in coffee callus cells. Zeitschrift fur Pflanzenphysiologie, v. 94, n. 2, 185-188, 1979.

STEINER, N. et al. Effect of carbon source on morphology and histodiffentiation of Araucaria angustifolia embryogenic cultures. Brazilian Archives of Biology and Technology, v. 48, n. 6, p. 895-903, 2005. Available from: <http://www.scielo.br/scielo. php?script $=$ sci arttext\&pid $=$ S1516-89132005000800005\&ln $\mathrm{g}=\mathrm{pt \& nrm}=\mathrm{iso}>$. Acessed at $11 \mathrm{dez}$. 2011. doi: http://dx.doi. org/10.1590/S1516-89132005000800005.

STEINMACHER, D. A. et al. A temporary immersion system improves in vitro regeneration of peach palm through secondary somatic embryogenesis. Annals of Botany, v. 108, n. 8, p.1-13, 2011. Available from: <http://aob.oxfordjournals.org/content/ early/2011/02/25/aob.mcr033.full.pdf + html $>$. Acessed at $23 \mathrm{jan}$. 2012. doi: 10.1093/aob/mcr033, available online at www.aob. oxfordjournals.org. 